\title{
Media Use in Estonia
}

\author{
Trends and Patterns ${ }^{l}$
}

\author{
Peeter Vihalemm
}

\begin{abstract}
The article gives an overview of general trends in media use in Estonia over the last 15 years, making some comparisons with Nordic countries.

Since the beginning of postcommunist transformation in 1991, the media landscape in Estonia has faced substantial changes. A completely renewed media system has emerged, characterized by a diversity of channels, formats, and contents. Not only the media themselves, but also the patterns of media use among audiences, their habits and expectations, have gone through a process of radical change. Changes in the Estonian media landscape have some aspects in common with many other European countries, such as the impact of emerging new media and global TV; others are specific features of transition to a market economy and democratic political order.

Besides discussing general trends, the article gives insights into some audience- related aspects of changes, more specifically age and ethnicity.
\end{abstract}

Key Words: media use, indicators of media landscape, changing functions of the media, postcommunist transformation, Estonia

\section{Introduction}

Despite the strong pressure of the Soviet propaganda system, Estonian-language journalism maintained its role as a social integrator and played an important role in cultural resistance of Estonians to the totalitarian regime (see Høyer, Lauk \& Vihalemm 1993; Vihalemm \& Lauristin 1997). Looking back at the 1970s and 1980s, general media use in Estonia was among the most active in the Soviet Union: the amount of radio listening and press reading was comparable to the very high levels of the Nordic countries. The Estonian language press was popular among all sectors of the population. In the early 1980s an average Estonian regularly read 7 newspapers and magazines (Lauristin et al 1987: 88).

According to surveys of the sociological research group of Estonian Radio and Estonian Television (see Vihalemm 2001), the average TV viewing time per day was 1 hour 30 minutes in 1976 and 2 hours in 1983-1985; radio listening time was 3 hours and 3 hours 10 minutes respectively (Saar 1985; Paulson 1986).

During the period of glasnost, when the multi-party system did not yet exist and the underground centres were weak, the media was the main mechanism of mass mobilisation (see Lauristin \& Vihalemm, 1993; Lauristin, 1998; Tapinas, 1998). In the first phase 
of postcommunist transition, characterised by the rise of the mass political movements (1987-1991), media in the three Baltic countries had played an active role in mobilisation and integration of people around national values (Hoyer, Lauk \& Vihalemm 1993; Lauristin \& Vihalemm 2002). Media use grew along with the audience's interest in politics, reaching a peak in 1989-1990. In 1990, according to a survey of the Department of Journalism at Tartu University, an average Estonian regularly read 12.5 newspapers and magazines. The 1989-1990 period was the peak of press circulation in all Estonian history. Three national dailies with circulations of 150,000-200,000 each, a cultural weekly with a circulation of 90,000, a women's magazine of 225,000 , etc. were published for a market of less than one million Estonians. In three years, 1988-1990, the total number of periodicals increased 3.7 times and their total circulation doubled.

Use of electronic media increased as well, though to a smaller extent compared to print media. The average radio listening time in 1989 was 3 hours 20 minutes per day, TV viewing time 2 hours 40 minutes respectively (Paulson 1993). During the period of mass political movements, broadcasting was extremely important as a mechanism of public participation.

Baltic opposition politicians fully utilised the ability of broadcast media - with their direct online access to a mass audience - to mobilise people and to stimulate protest movements. For instance, the two-million-person demonstration "Baltic chain", organised on 23 August 1989, the 50 th anniversary of the Molotov-Ribbentrop pact, was not only directly broadcast on all radio and TV channels in Estonia, Latvia and Lithuania, but it was also organised and managed with the assistance of the media.

After the restoration of Estonian independence in August 1991, a new political and economic environment brought major changes in the media system and in the character of media use.

During the second stage of transition in 1991-1994, liberalisation of the press was closely related to abolition of state ownership and subsidies for the print media. Most of the newspapers were privatised and hundreds of new periodicals established. At the same time, a rapid generational turnover of journalists occurred (see Lauk, 1996, 1997). The new generation of journalists did not share the experiences and role models of their older colleagues, who took for granted an important political role for journalists in society. The new journalists quickly accepted an Anglo-Saxon model of news journalism and accepted marketisation of journalism as a natural process. The products of journalistic activities were increasingly evaluated according to their "sale value" as profitable goods, not as socially and culturally valuable texts. Competition for the attention of the audience has brought about changes in the content and functions of the media. Information and entertainment have intertwined, superseding analysis, enlightenment, and social integration (Vihalemm, Lauk \& Lauristin 1997; Lauristin \& Vihalemm 2002; Lauk \& Harro 2003).

Increasing living costs, including a rise in the prices of newspapers and magazines (in the interval 1991-1996 they rose about three times more than the prices of other goods and services) led to a dramatic decrease in circulation and subscription to Estonian press publications. The pattern of media usage among Estonians also changed: reading newspapers became a more elite habit; many people were no longer able to subscribe even to one newspaper.

With the ongoing privatisation of the newspaper media, new magazines and private radio and TV channels were also launched. The result was a growing diversification and fragmentation of the media in the 1990s: instead of a few channels followed by a ma- 
jority of the people, there was a growing number of channels followed by specific, smaller audiences.

Along with the establishment of new commercial radio stations from 1991 and commercial TV stations from 1993 onwards, the time spent on electronic media increased. At the same time, consumption of the printed press decreased. In 1995, compared to 1990, an average Estonian was reading regularly two times fewer newspapers and magazines (6.1); whereas the average radio listening time per day had grown to 4 hours and 12 minutes, TV viewing time increased to 3 hours 28 minutes (Lauristin \& Vihalemm 1998: 33).

\section{The Recent Picture: Stabilisation on New Levels}

Since 1995 newspaper reading has stabilised, with a tendency toward a slight decrease. During the second half of the 1990s, when the first shock of radical reforms was over and the living standard of Estonian population started to rise, a large number of new magazines was launched. The number of magazines and other periodicals increased seven times during the 1990s. The growth in magazine reading was much more modest but still remarkable. Trends in radio listening and TV viewing moved in opposite directions - the average radio listening time decreased in the late 1990s, while TV viewing increased (Lauristin \& Vihalemm 1998: 33).

Comparing the levels of Estonians' media use in 1999 with the level of 1984, we can see a decrease in newspaper reading, maintenance of the same level in magazine reading, and a remarkable increase in radio listing and especially in TV viewing - see Table 1.

Table 2 characterises the level of media use in 2004 in comparison with 2000. Table 3 presents general indicators of media use in the years 2000-2004 (in November of the respective year).

Radio listening stabilised during the years 2000-2002 at a level of 3 hours 29 minutes, measured in autumn of the each respective year). The average TV viewing time has continually increased, with an average of 4 hours 30 minutes for the year 2002. In international comparison Estonia reached the level of the TOP 5 television viewing countries in Europe and in the world (Hasebrink \& Herzog 2004: 147).

It is important to mention that changes in TV viewing and radio listening figures in 2003 and 2004 compared to previous years reflect changes in methodology, not in actual media use. ${ }^{2}$ In early 2003 the leading Estonian opinion and market research company TNS Emor, which has been carrying out audience monitoring since 1993, introduced TV meters (electronic devices connected to TV sets) to replace TV viewing diaries. Changes were also made in sample composition: instead of population aged 12-74, all people older than 4 years were included in the survey. Because of these changes in data collection methodology, it is important to point out that the data in the Table 1, reflecting TV viewing and radio listening in 2003 and 2004, are not exactly comparable with the data from 2000-2002.

The Internet arrived in Estonia relatively early, in June 1992. Since 1995 Internet access and usage have increased rapidly (see Herron 1999), currently placing Estonia among the top 10 countries in the European Union with respect to Internet penetration (Europe Internet Usage 2004) and online availability of public services (Online services 2004).

On the basis of the data presented above, we can conclude that the average TV viewing time in Estonia increased remarkably up to the year 2003 and then stabilised. We can 
Table 1. Trends in Estonians' Media Use, 1984-1999 (1984=100)

\begin{tabular}{lccrrr} 
& 1984 & 1990 & 1994 & 1997 & 1999 \\
\hline $\begin{array}{l}\text { Average number of newspapers regularly read } \\
\text { Average number of magazines and other }\end{array}$ & 100 & 152 & 110 & 95 & 80 \\
periodicals regularly read & 100 & 135 & 62 & 92 & 105 \\
Average TV viewing time per day & 100 & 128 & 146 & 180 & 185 \\
Average radio listening time per day & 100 & 125 & 155 & 132 & 130 \\
\hline
\end{tabular}

Sources: Research Dep. of Estonian Radio, Dep. of Journalism at Tartu University, TNS Emor (BMF Gallup Media).

Table 2. Recent Trends of Media Use in Estonia 2000-2004 (2000=100)

\begin{tabular}{lccccc} 
& 2000 & 2001 & 2002 & 2003 & 2004 \\
\hline Average number of newspapers regularly read & 100 & 99 & 94 & 93 & 87 \\
Average number of periodicals regularly read & 100 & 102 & 92 & 90 & 75 \\
Average TV viewing time per day & 100 & 106 & 115 & $96^{*}$ & $97^{*}$ \\
Average radio listening time per day & 100 & 100 & 100 & $140^{*}$ & $135^{*}$ \\
Share of Internet users & 100 & 115 & 154 & 165 & 168 \\
\hline
\end{tabular}

* Change in data collection methodology since January 2003 - TV meters introduced instead of viewers' diaries, and more precise determination of radio listening.

Source: TNS Emor.

Table 3. Aggregated Indicators of Media Use in Estonia, 2000-2004

\begin{tabular}{lrrrrr} 
& 2000 & 2001 & 2002 & 2003 & 2004 \\
\hline Newspaper reading & & & & & \\
General reading (share of readers, $\%^{1}$ ) & 94.5 & 93.8 & 95.3 & 92.0 & 90.8 \\
Regular readers (share of readers, $\%^{2}$ ) & 79.0 & 75.9 & 78.1 & 74.5 & 70.5 \\
Average number of newspapers generally read & 4.05 & 3.69 & 3.86 & 3.71 & 3.35 \\
Average number of newspapers regularly read & 2.11 & 2.08 & 1.98 & 1.97 & 1.83 \\
Reading of magazines & & & & & \\
General reading (share of readers, \% ${ }^{3}$ ) & 86.3 & 85.9 & 85.3 & 85.3 & 80,7 \\
Regular readers (share of readers, \% ${ }^{4}$ ) & 72.3 & 73.1 & 71.3 & 69.7 & 63,8 \\
Average number of magazines generally read & 5.57 & 5.47 & 4.96 & 4.65 & 3.99 \\
Average number of magazines regularly read & 2.55 & 2.59 & 2.35 & 2.30 & 1.92 \\
Radio: average listening time per day (h: min) & $3: 29$ & $3: 29$ & $3: 29$ & $4: 52^{*}$ & $4: 41^{*}$ \\
Television: viewing time per day (h: min) & $4: 14$ & $4: 28$ & $4: 50$ & $4: 04^{*}$ & $4: 06^{*}$ \\
Internet: have used during last six months (\%) & 28.2 & 32.5 & 43.5 & 46.6 & $47.4^{* *}$ \\
\hline
\end{tabular}

${ }^{1}$ Have read at least one of the last six issues of any newspaper

${ }^{2}$ Have read at least four of the last six issues of any newspaper

${ }^{3}$ Have read at least one of the last six issues of any magazine or other periodical

${ }^{4}$ Have read at least four of the last six issues of any magazine or other periodical

* Change in data collection methodology since January 2003 - TV meters introduced instead of viewers' diaries, more precise determination of radio listening.

** These data contradict TNS Emor Internet usage survey data from spring 2004 when the ratio of Internet users among population aged 6-74 was 52\% - Emor 2004.

Source: TNS Emor Ltd. 
also conclude that the general amount of radio listening has been quite stable, remaining on the same level in 2000-2002, and decreasing only slightly from the year 2003 to 2004.

Radio listening is predominantly (over 90 per cent of the total listening time) a parallel activity to working, driving, talking, eating, etc. As a main activity, it took up only about 20 minutes per day in the years 1976-1983 (Lõhmus \& Vihalemm 2004: 108). Presumably the share of radio listening as a main activity has decreased even more during the last two decades, due to the increasing role of music and entertainment in the content of radio programs.

When analysing press reading in Estonia, a distinction is usually made between two levels of reading - regular and irregular. As empirical indicators of reading regularity we have used answers to the question, "Have you read some of each of the last six issues of this publication?" Reading from at least four of the last six issues has been interpreted as regular reading, one to three issues as irregular reading. ${ }^{3}$ In the following analysis we have used indices of regular contacts with newspapers and magazines based on aggregated answers about regularity of reading for all newspapers and respectively also for all magazines.

In Table 3 press reading is characterised by two kinds of aggregated indicators, which are complementary to each other - the share of people who generally and regularly read newspapers, magazines, and other periodicals (according to the above-mentioned criteria, used by the TNS Emor) and the average number of generally and regularly read newspapers and magazines. These indicators highlight slightly different trends in press reading. On the basis of Table 3 we can conclude that the share of newspaper readers among the Estonian adult population was quite stable in 2000-2002 and was slightly decreasing in 2003-2004. Only about 5-10 per cent do not read any newspapers at all, but a much larger number of people, 25-30 per cent, do not read newspapers regularly. As we can see from below, there is also a difference in regular newspaper reading between Estonians and non-Estonians; between the young generation on the one hand, and middle-aged and elderly people on the other. At the same time the average number of newspapers read regularly or irregularly is clearly decreasing.

Comparing the data for the average number of newspapers read by the Estonian population with the circulation figures, we noticed that the average decrease in newspaper circulation that occurred in 1990-1995 was much greater than the decline in newspaper reading (Vihalemm \& Juha 2004: 305). We can assume that one copy of a newspaper was read by more people than in Soviet times, when newspapers were very cheap. People began to read at workplaces and in libraries, to borrow a paper from a neighbour, etc. In recent years the opposite trend can be seen: a clear decline in newspapers reading concurrent with slightly increasing circulation, meaning a decrease in the number of readers per copy.

Compared to newspapers, recent trends in reading magazines and other periodicals are relatively similar, with the exception that the number of periodicals read by the average Estonian decreased in 2004 more than the number of newspapers. Since the year 2000 , the interest in magazine reading, initially boosted by a new variety of titles, formats, and topics, started to decrease.

Summarising the time devoted to the daily media use among the adult Estonian population, one can estimate that the length of an average media day is 9 hours 20 minutes. This time is spent overwhelmingly with broadcasting ( 8 hours and 25 minutes), while the estimated time for press reading and Internet usage is only 55 minutes. 


\section{Social Factors of Media Use}

The long tradition of media and communication research in Estonia (see Vihalemm 2001) has given us an opportunity to trace how social factors affecting media use have changed throughout the last decades.

According to surveys carried out by the Department of Journalism at Tartu University and by the sociological research group of Estonian Radio and Estonian TV in the 1970 s and 1980s, the main differentiating factors of general media use during the Soviet era were education and ethnicity (see Lauristin et al 1987; Vihalemm 2004). These surveys revealed that in the life of local Russians, press reading and radio listening played a remarkably smaller role. The Russian-speaking population, mainly post-war immigrants, were not associated with local cultural traditions and did not use Estonian language media. Besides a weaker reading tradition, a crucial factor was doubtless the fact that in Estonia there were fewer available Russian-language media channels. At the same time, Estonians had a long tradition of newspaper reading. Estonian newspapers and magazines had been an important part of national integration since the middle of the 19 th century, and had also preserved this function under Soviet rule (see Hoyer, Lauk \& Vihalemm 1993).

Education had a notable influence on press reading (more highly educated people read more), and a smaller effect on radio listening and TV viewing (people with higher education were less active listeners and viewers).

The indicators of current media use in different demographic groups are presented in Tables 4 and 5. Table 4 characterises general media consumption in the main demographic groups in November 2004 on the basis of the same aggregated indicators used in Table 3. Table 5 presents differences in general media use in comparison with the average of the total population. Data in these tables demonstrate that the average number of regularly read newspapers could be chosen as the most distinctive indicator; in the area of magazine reading this could be the average number of magazines and other periodicals generally read.

On the basis of Tables 4 and 5, we can conclude that ethnicity remains one of the main factors affecting media use. It influences consumption of traditional media more than the Internet. A very strong influence on press reading continues to be education, the role of which has increased over the last decade.

During Soviet times, regular reading of several national and local newspapers was quite common in all social groups. Even very specific cultural publications had a large and democratic audience. Due to the quite limited possibilities for political and economic activities, the cultural press (literary magazines, the cultural weekly) became an important carrier of cultural opposition to the Soviet system. For people deprived of political and economic freedom, reading books, as well as the cultural press performed an important compensatory function (see Vihalemm \& Lauristin 1997). With the coming of a free market society, this integrative and compensatory role of the press has diminished. The previous democratic character of the readership of cultural publications has narrowed. Due to rising prices and changing functions of the media, reading quality newspapers has become more limited to elite groups of society. In 1990-2001 the circulation of the cultural weekly dropped 25 fold; circulation of the two leading national dailies 3,5 fold. The share of people with higher education in the audience of the two leading national dailies has increased by $47 \%$, whereas its share in the audience of the cultural weekly has even grown 2.3 fold (Vihalemm \& Kõuts 2004: 74; Vihalemm \& Juha 2004: 307, 339). 


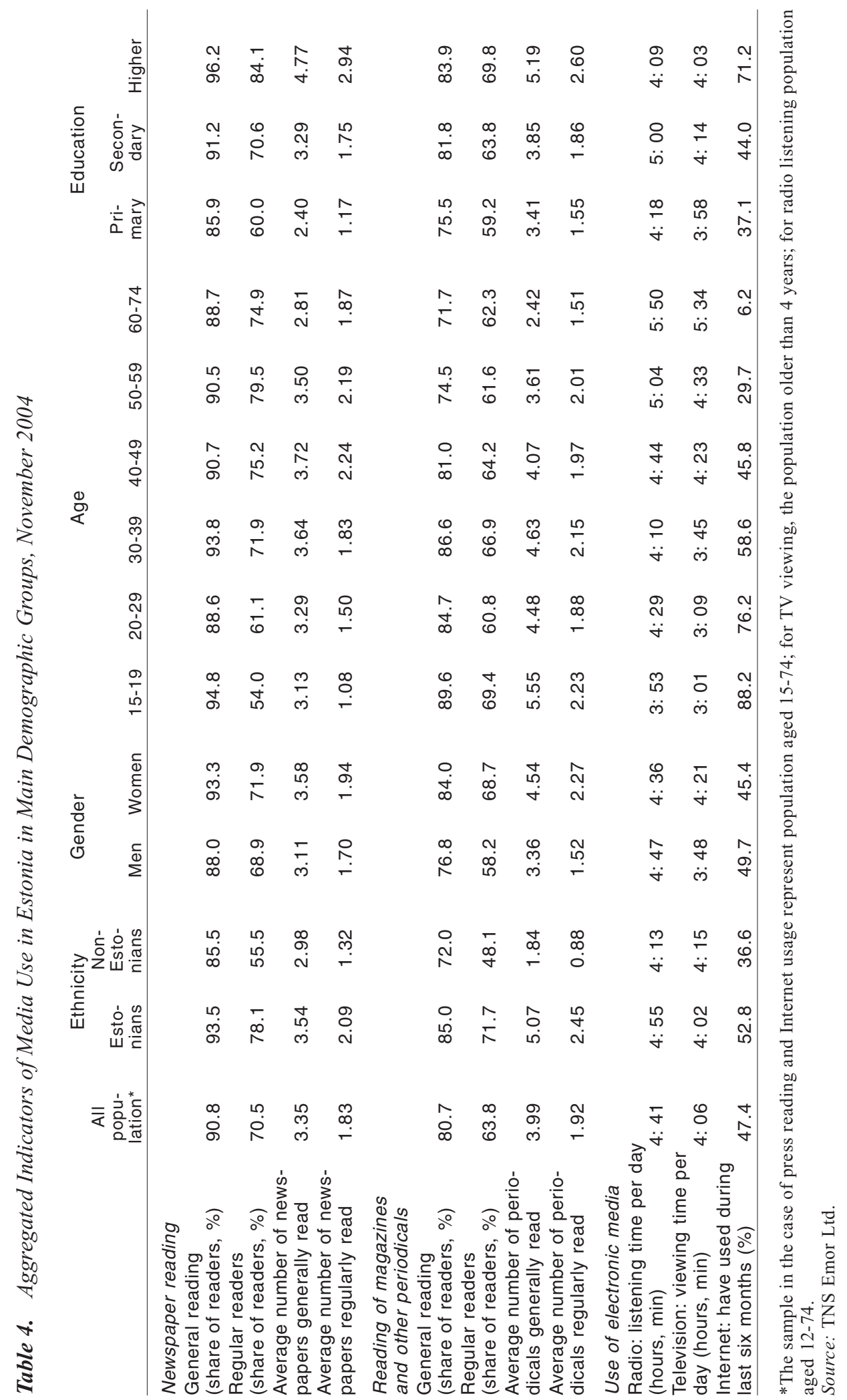




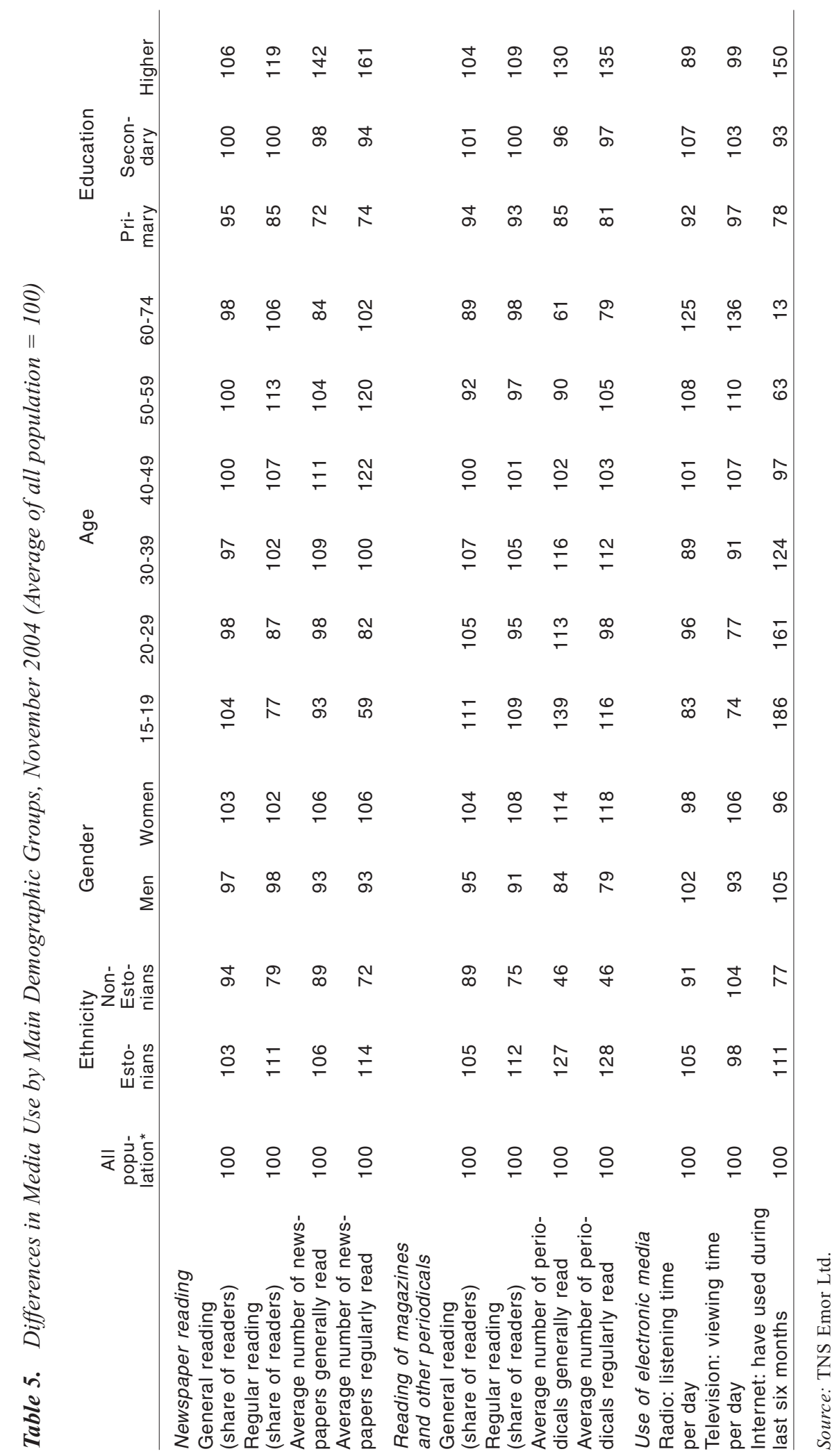


Age has become a new and very important factor impacting general media use. Large disparities between the age groups appear not only in Internet usage but also in newspaper and magazine reading, radio listening, and TV viewing. The youngest group (aged 15-19) makes more frequent use of the Internet than the second group (aged 20-29), and for multiple purposes: entertainment, reading newspapers and magazines, listening to music and following RV and radio programs, studying and communicating with friends (Vengerfeldt \& Runnel 2004). This trend indicates the beginning of a fundamental shift in media usage in Estonia: among the youngest age group we can speak about an Internet-centred media environment and, as a matter of fact, about media convergence.

Comparing the patterns of general media use in different age groups (Figure 1), one can see that the Estonian young generation is clearly oriented to the Internet and reads significantly more general-interest magazines, whereas the older generation is oriented to $\mathrm{TV}$ viewing and radio listening.

It is important to mention that even if the young generation demonstrates the same level of newspaper reading, there is a larger share of irregular readers among them, who perhaps browse through the content of newspapers via the Internet. This is a characteristic feature of their newspaper reading, but not of magazine reading.

\section{Comparison of Media Use Trends in Estonia, Finland and Sweden}

The recent changes in media use by Estonians seem quite dramatic, compared to the relatively stable picture of media use in the Nordic countries. Media use volume in Sweden has been quite stable over decades - average time for radio listening was 133 minutes per day as in 1986 as well in 1999, for TV viewing respectively 100 and 98 minutes, for newspaper reading 34 minutes and 28 minutes (Nordicom-Sveriges Mediebarometer 2003: 21). Although radio and TV trends in Finland over 1986-1999 have been relatively similar to Estonia (average radio listening time has grown by $31 \%$ and

Figure 1. Patterns of Media Use in Different Age Groups (Percentage of difference from average level in November 2004)

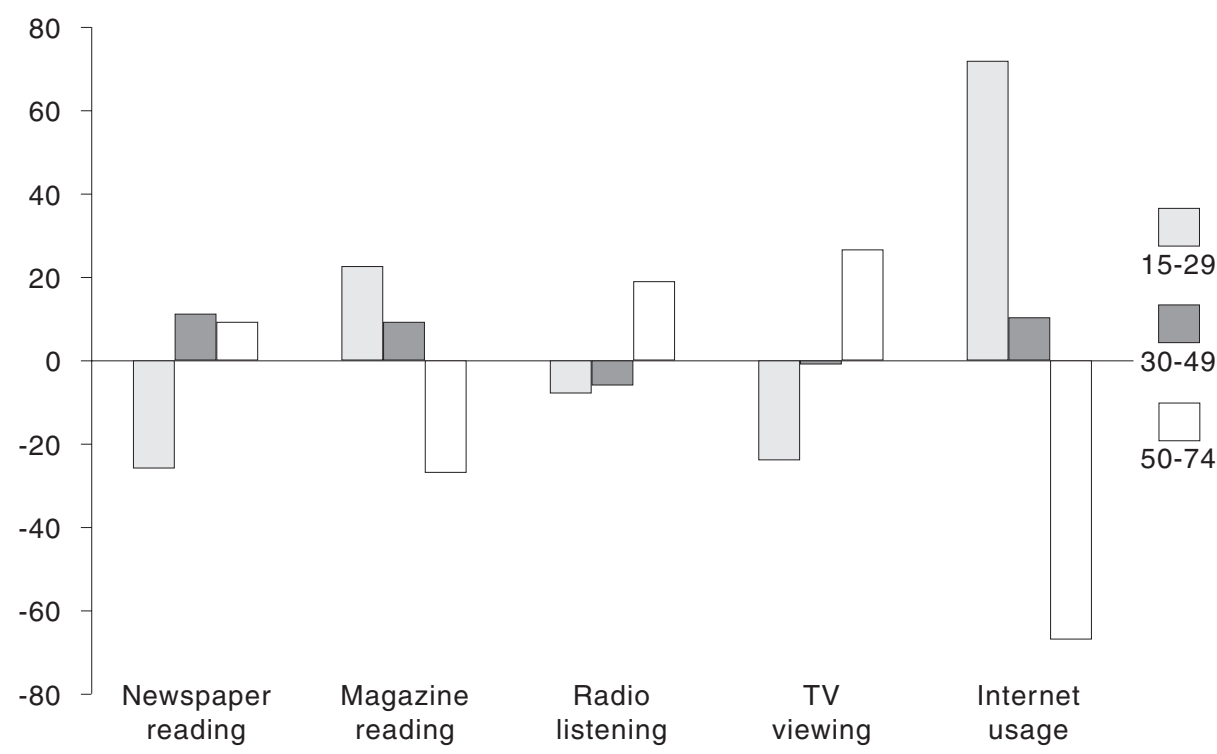


TV viewing time by 59\%), newspaper reading (average newspaper reading time) has also been quite stable in Finland across the three decades 1971-2000, with a very slight decrease in the mid-1990s (see Wiio \& Nordenstreng 2003: 14).

The average media day of Estonian users is longer than in the Nordic countries: approximately an hour longer than in Finland ( 8 hours and 14 minutes in 2002 according to World Press Trends $2003^{4}$ ) and about two hours longer than in Norway and Denmark, but over four hours longer than in Sweden. Media use in Estonia can be characterised by very active radio listening and TV viewing. Only in Ireland is the average listening time longer than in Estonia (World Press Trends 2003: 149); the average TV viewing in 2002 was exceeded only by Macedonia, the USA, and Hungary (Television 2003 International Key Facts). The very approximate figure of time spent in Estonia on reading printed media and using Internet seems quite comparable with the Nordic countries: in Finland in 2002 it was 1 hour and 34 minutes (World Press Trends 2003: 116); in Sweden in 2003, 1 hour and 8 minutes (Nordicom-Sveriges Mediebarometer 2003: 23); in Germany in 2003, 1 hour 2 minutes (World Press Trends 2004: 155).

Comparing our data about the age groups with the data showing the average time spent in 2003 on different media channels in Sweden, one can see similar trends in newspaper reading and radio listening in both countries: young people are reading newspapers less and listening less to the radio (time spent in Sweden on reading dailies in age group 15-24 was 53\% from an average of the whole population, that of radio listening $74 \%$ respectively). However, Swedish youth watches more TV and reads fewer magazines than average: time spent on watching TV was $107 \%$ compared to the average, and $67 \%$ spent on magazine reading. Internet usage is more similar between the age groups in Sweden than in Estonia, although the oldest age group 65-79 differs greatly from the average (Nordicom-Sveriges Mediebarometer 2003: 23).

Comparison of the data concerning the average time spent on different media in Finland (Finnish Mass Media 2004) shows quite similar trends with Sweden with respect to radio listening, but not for magazine reading and TV viewing. In Finland there are no differences between age groups in average time for magazine reading (Finnish Mass Media 2004: 222). Similarly to Estonia the young generation is spending much less time on TV viewing, compared to middle aged and older people. In all three countries young people are less active newspaper readers, compared to the other age groups (Table 6).

Table 6. Comparison of Traditional Media Use by Age Groups in Three Countries (Average of adult population in respective country $=100$ )

\begin{tabular}{lrrrrrrrrrr} 
& \multicolumn{3}{c}{ Estonia 2004 } & \multicolumn{3}{c}{ Sweden 2003 } & \multicolumn{3}{c}{ Finland 2002-04* } \\
& $15-19$ & $40-59$ & $60-74$ & $15-24$ & $45-64$ & $65-79$ & $15-24$ & $45-64$ & $65-$ \\
\hline Newspaper reading $^{* *}$ & 59 & 121 & 102 & 53 & 120 & 170 & 52 & 127 & 165 \\
Magazine reading** $^{*}$ & 116 & 104 & 79 & 67 & 113 & 153 & 97 & 97 & 106 \\
Radio istening $^{* * *}$ & 83 & 104 & 125 & 74 & 116 & 121 & 68 & 121 & 130 \\
TV viewing $^{* * *}$ & 74 & 108 & 136 & 107 & 98 & 124 & 61 & 116 & 153 \\
\hline
\end{tabular}

* Press reading data are based on a slightly different age classification: 12-24, 45-59, and over 60

** In Sweden and Finland, average reading time per day; in Estonia, the number of regularly read newspapers/magazines and other periodicals

***Average listening and viewing time per day

Sources: TNS Emor, Nordicom-Sveriges Mediebarometer 2003, Finnish Mass Media 2004. 
The most active newspaper readers in Finland as in Sweden are older people, while in Estonia the most active press readers are middle-aged people (age 40-59). It seems that the common trend, aging of the newspaper readership, began among Estonian readership later, only after the 1990s, while in the Nordic countries this tendency emerged already in the middle of the 1980s.

On the basis of the data about the daily reach of newspapers in age groups it can also be concluded that in many other countries (France, Germany, the USA) there is a trend toward more occasional newspaper reading among young people, compared to the middle aged and especially the older generation. There are some exceptions, however, for example, Norway, the UK, Lithuania (World Press Trends 2004). The regularity of newspaper reading among young people in Finland decreased significantly in the years 1985-1999, but has stabilised at the beginning of the new century (Hujanen 2002). In Estonia there has been much discussion concerning the aging of newspaper readers and possible strategies for bringing back younger readers.

\section{Concluding Remarks}

1. The patterns of general media use in the main demographic groups clearly demonstrate differences, not only in use of the new media but also in use of traditional media. This allows us to argue that we should speak about a media divide, not only about a digital divide (see Vihalemm \& Lauristin 2002).

2. General media use in Estonia during the recent years can be characterised by the increasing importance of the electronic media. This means not only a rapid increase in Internet usage (by 2004 the share of Internet users had reached half of the Estonian population), but also a marked increase in time spent on TV watching. Both trends are common for all European countries. However, growth in TV watching has been dramatic - not only in Estonia as compared to Nordic countries, but as a trend typical of all postcommunist societies. This is probably connected with a greater need for relaxation, caused by rapid transformation in all spheres of life, and by a turn to the more intensive and demanding situation of permanent competition.

3. Among the social factors of media use, ethnicity, education, and age are of the greatest general importance. The majority of Estonian Russians are oriented to Russian media (particularly TV); their traditions of press reading and radio listening are weaker compared to Estonians. For younger people, the Internet is of much greater importance. The younger generation is also more entertainment-oriented, reading fewer newspapers and more general interest magazines compared to middle-aged and older people, and preferring commercial radio and TV channels to the public ones.

4. The uses of traditional and new media are in general complementary to each other. Only in the youngest group (aged 15-19) can we observe that with the Internet becoming a multifunctional channel, the use of traditional media (particularly TV) is on the decrease. In a significant group of people (21 per cent of all respondents) the Internet and interpersonal communication at the workplace or in school were evaluated as much more important sources for news and knowledge than TV newscasts, which were clearly leading sources for the majority of the population.

5. The main problem with international comparisons is the lack of comparable data on media systems and especially on media use. In situations where the data about media use 
in different countries are based on different indicators and different methodology, crossnational comparisons could be made using differences drawn from the average of the total population, and measured by the particular set of indicators in the each country.

6. There is a need for an international agreement concerning key indicators in the field of media and for an agreement on the harmonisation of methodology and criteria of data gathering. Such an agreement should be made on the basis of international discussion among researchers, and initiated by the EU institutions.

\section{Notes}

1. The article is based on research supported by the Estonian Ministry of Education and Science (research theme 1774) and Estonian Science Foundation (grant 6526).

2. As the result of more precise determination of viewing time, the average TV viewing time became shorter. Comparing the data from November 2002 and November 2003, the decrease was 44 minutes (see Table 3). An additional effect was obviously produced by the extended age limits of the sample, as the amount of viewing time among the age groups 4-14 and over 75 is a bit smaller, compared to the average of the previous sample (covering ages from 15 to 74 ). The fact that the average TV viewing time in November 2004 has not changed compared to the data of November 2003 (4 hours 6 minutes and 4 hours 4 minutes respectively) proves our assumption about the effects of methodology as the reason why the data from 2002 and 2003 are so different.

In 2003 some important changes were also introduced in data collection methodology concerning radio audiences. Since January 2003, the listener's diary has become more precise; respondents are instructed that they should not only mark what radio channel they are listening to, but also where they are doing it - at home, at the workplace, in a car. Table 3 shows that as a result of this change, much more frequent determination of occasional radio listening had taken place, and the average listening time has increased for almost one and a half hour per day. Besides the mentioned change in the diary format, there is no other reason to expect such a big increase in radio listening time, which has been very stable for years.

3. These indicators have been used by the leading Estonian marketing research and consulting company TNS Emor Ltd, presented also in Tables 3 and 4 (general reading = regular + irregular reading).

4. These data contradict the data of the Intermedia research conducted by Finnish Gallup in $2002-$ according to them the average media day in Finland was 9 hours and 22 minutes, quite similarly to Estonia (Wiio \& Nordenstreng 2003: 15).

\section{References}

Emor 2004 - The number of Internet users in Estonia has exceeded 600000 . Emor news archive 22.06.2004. www.emor.ee/eng/arhiiv.html? keyword=31

Europe Internet Usage 2004 - Europe Internet Usage Stats and 2004 Population Statistics. www. internetworldstats.com/stats4.htm

Finnish Mass Media 2002, 2004. Helsinki: Statistics Finland.

Hasebrink, Uwe \& Anja Herzog (2004) Mediennutzung im internationalen Vergleich. In Christiane Matzen \& Anja Herzog (ed) Internationale Handbuch Medien 2004/2005. Baden-Baden: Nomos.

Herron, Erik (1999) Democratization and the Development of Information Regimes: The Internet in Eurasia and in the Baltics. Problems of Post-Communism, 46, 6, 56-68.

Høyer, Svennik; Epp Lauk \& Peeter Vihalemm (eds) (1993) Towards a Civic Society: The Baltic Media's Long Road to Freedom. Tartu: Baltic Association for Media Research/Nota Baltica Ltd.

Hujanen, Erkki (2002) Sanomalehtien tilaamattomuus. In Finnish Mass Media 2002. Helsinki: Statistics Finland.

Lauk, Epp (1996) Estonian Journalists in Search of New Professional Identity. Javnost/The Public, 3, 4, 93-106.

Lauk, Epp (1997) Historical and Sociological Perspectives on the Development of Estonian Journalism. Dissertationes de mediis et communicationibus Universitatis Tartuensis 1. Tartu: Tartu University Press.

Lauk, Epp \& Halliki Harro (2003) A Landscape After the Storm: Development of the Estonian Media in the 1990s. In David Paletz \& Karol Jakubowicz (eds) Business as Usual: Continuity and Change in Central and Eastern European Media. Creskill, NJ: Hampton Press.

Lauristin, Marju (1998) Transformations of Public Sphere and Changing Role of the Media in PostCommunist Society. In Piotr Sztompka (ed.) Building Open Society and Perspectives of Sociology in 
East-Central Europe. Pre-Congress Volumes of the $14^{\text {th }}$ World Congress of Sociology. Montreal: International Sociological Association.

Lauristin, Marju; Peeter Vihalemm; Sulev Uus \& Juhan Peegel (1987) Rajoonileht ja lugeja [Local paper and its reader]. Tallinn: Eesti Raamat.

Lauristin, Marju \& Vihalemm, Peeter (1993) The Awakening. In Svennik Høyer; Epp Lauk \& Peeter Vihalemm (eds) (1993) Towards a Civic Society: The Baltic Media's Long Road to Freedom. Tartu: Baltic Association for Media Research/Nota Baltica Ltd.

Lauristin, Marju \& Peeter Vihalemm (1998) Media Use and Social Changes in Estonia. In Estonian Human Development Report 1998. Tallinn: UNDP. Available electronically - www.iiss.ee/nhdr/1998/ EIA98eng.pdf

Lauristin, Marju \& Peeter Vihalemm (2002) The Transformation of Estonian Society and Media: 19872001. In Peeter Vihalemm (ed) Baltic Media in Transition. Tartu: Tartu University Press.

Lõhmus, Maarja \& Peeter Vihalemm (2004) Raadio Eestis 1960-2004: struktuur, programm ja kuulajad (Radio in Estonia in 1960-2004: structure, programme and listeners). In Peeter Vihalemm (ed) Meediasüsteem ja meediakasutus Eestis 1965-2004. Tartu: Tartu Ülikooli Kirjastus.

Nordicom-Sveriges Mediebarometer 2003. MedieNotiser 1, 2004. Göteborg: Nordicom-Sverige \& Göteborgs universitet.

Online services 2004 - Online Availability of Public Services: How is Europe Progressing? Report of the Fifth Measurement, October 2004. http://europa.eu.int/information_society/soccul/egov/egov_ benchmarking_2005.pdf

Paulson, Tiiu (1986) Auditooriumist [About audience]. In ENSV Teleraadiokomitee panoraam 1985. Tallinn: Eesti Raamat.

Paulson, Tiiu (1993) Eesti NSVst Eesti Vabariiki. Käsikiri (From ESSR to Estonian Republic. Mimeo). Tallinn: Telirad.

Saar, Andrus (1985) TV ja raadio auditooriumi uurimise tulemusi [Results of broadcasting audience research]. In ENSV Teleraadiokomitee panoraam 1984. Tallinn: Eesti Raamat.

Tapinas, Laimonas (1998) The Print Media. In Helga Schmid (ed.) Understanding the Media in the Baltic States. Düsseldorf: European Institute for the Media.

Television 2003 - International Key Facts (2003) Köln: RTL Group \& IP International Marketing Committee.

Vengerfeldt, Pille \& Pille Runnel (2004) Uus meedia Eestis [New media in Estonia]. In Peeter Vihalemm (ed) Meediasüsteem ja meediakasutus Eestis 1965-2004. Tartu: Tartu Ülikooli Kirjastus.

Vihalemm, Peeter (2001) Development of Media Research in Estonia. Nordicom Review, 22, 2, 79-92.

Vihalemm, Peeter (ed) Meediasüsteem ja meediakasutus Eestis 1965-2004 (Media system and media use in Estonia in 1965-2004). Tartu: Tartu Ülikooli Kirjastus.

Vihalemm Peeter; Epp Lauk \& Marju Lauristin (1997) Estonian Media in the Process of Change. In Marju Lauristin \& Peeter Vihalemm with Karl Erik Rosengren \& Lennart Weibull (eds) Return to the Western World: Cultural and Political Perspectives on Estonian Post-Communist Transition. Tartu: Tartu University Press.

Vihalemm, Peeter \& Marju Lauristin (1997) Political Control and Ideological Canonisation. The Estonian Press during the Soviet Period. In Eduard Mühle (ed) Vom Instrument der Partei zur "vierten Gewalt”. Marburg: Herder-Institut.

Vihalemm, Peeter \& Marju Lauristin (2002) Indicators of Media Development in Estonia. In Defining 'Key Indicators' in the Field of Media and Communication Research in Europe. Conference Papers. Dortmund : University of Dortmund.

Vihalemm, Peeter \& Leie Juha (2004) Trükisõna ja lugejad (Printed media and readers). In Peeter Vihalemm (ed), Meediasüsteem ja meediakasutus Eestis 1965-2004. Tartu: Tartu Ülikooli Kirjastus.

Vihalemm, Peeter \& Ragne Kõuts (2004) Trükisõna ja lugejaskond Eestis 1965-2004 (Printed media and its audience in Estonia in 1965-2004). In Peeter Vihalemm (ed) Meediasüsteem ja meediakasutus Eestis 1965-2004. Tartu: Tartu Ülikooli Kirjastus.

Vihalemm, Triin (1999) Local and Global Orientations of Media Consumption in Estonia. In Estonian Human Development Report 1999. Tallinn: UNDP. Available electronically - www.iiss.ee/nhdr/1999/ EIA99eng.pdf

Wiio, Osmo \& Kaarle Nordenstreng, Kaarle (2003) Viestintäjärjelstelmä. In Kaarle Nordenstreng \& Osmo Wiio (ed) Suomen mediamaisema. 2. painos. Vantaa: WSOY.

World Press Trends 2003 (2004). Paris: World Association of Newspapers \& Zenithmedia.

Peeter Vihalemm, Professor, Department of Journalism and Communication, University of Tartu, Ülikooli 18, EE-Tartu 50090, peeter.vihalemm@ut.ee 